\title{
Influence of organic manures, inorganic fertilizers and bio-fertilizers on yield and quality attributes of potato (Solanum tuberosum L.)
}

Alexandre Congera ( $\sim$ ac286448@gmail.com )

University of Horticultural Sciences Bagalkote

ANJANAPPA M.

University of Horticultural Sciences Bagalkote

INDIRESH K.M.

University of Horticultural Sciences Bagalkote

BASAVARAJA P.K.

University of Agricultural Sciences, Bangalore

MUNIRAJAPPA R.

University of Agricultural Sciences, Bangalore

\section{Research Article}

Keywords: Potato, Organic, Inorganic, Manures, biofertilizers, Kufri Jyoti, quality attributes

Posted Date: February 8th, 2021

DOI: https://doi.org/10.21203/rs.3.rs-150214/v1

License: (9) This work is licensed under a Creative Commons Attribution 4.0 International License.

Read Full License 


\section{Abstract}

Studies on effect of organic, inorganic and bio-fertilizers on yield and quality attributes of potato (Solanum tuberosum L.) variety Kufri Jyoti, comprising of 10 different treatments using randomized complete block design with three replications were conducted at Post Graduate Centre, University of Horticultural Sciences, Campus, Gandhi Krishi Vignana Kendra, Bangalore during Rabi 2011. Application of $50 \%$ RDF $+50 \% \mathrm{FYM}+$ Azotobacter + Phosphobacteria $\left(T_{7}\right)$ showed significantly maximum number of tubers per plant (7.87), tuber yield per plant (363.33 $\mathrm{g} \mathrm{plant}^{-1}$ ) and tuber yield per hectare $\left(34.13 \mathrm{t} \mathrm{ha}^{-1}\right)$. This treatment also produced maximum tuber dry matter $(21.67 \%)$, starch content $(78.20 \%)$ non-reducing sugars $(0.84 \%)$ and total sugars $(1.74 \%)$ which were on par with $T_{3}, T_{4}$ and $T_{6}$ during rabi 2011.

\section{Introduction}

Potato (Solanum tubevosum L.) is one of the most important food crops after wheat, maize and rice owing to its great yield potential, high nutritive value and accounts for nearly half of the worlds annual output of all root and tuber crops (Dibyendu et al., 2010) ${ }^{5}$. It is a heavy feeder of plant nutrients having higher requirement of nitrogen, phosphorus, potassium and other nutrients. Singh and Kushwah $(2006)^{20}$ suggested the combined use of organic and inorganic sources of nutrients in potato. But presently, there is no information regarding integrated nutrient management for achievement of different yield of "Kufri Jyoti" potato which is the major cultivated variety of the region. Keeping above factors in view, an experiment was conducted with "Kufri Jyoti" potato.

\section{Materials And Methods}

A field experiment was conducted at the University of Horticultural Sciences, Post Graduate Centre, Campus, Gandhi Krishi Vignana Kendra (GKVK), Bangalore during Rabi 2011. The experimental field was located at the latitude of $13^{\circ} 04^{\prime}$ North and longitude of $77^{\circ} 34^{\prime}$ East with an altitude of 921 meters above the mean sea level. The maximum and minimum temperatures in a year range between $29.1^{0} \mathrm{C}$ and $17.4^{0}$ $C$ respectively (Anon, 2010) ${ }^{1}$. The soil of the experimental field was sandy loam having 6.28 to $7.16 \mathrm{pH}$. The experiment was laid out in Randomized Completely Block Design with three replications involving 10 treatments viz, 100\% recommended dose of fertilizer (125:100:125 $\left.\mathrm{kg} \mathrm{NPK} \mathrm{ha}^{-1}\right)\left(\mathrm{T}_{1}\right) ; 100 \% \mathrm{RDF}+100 \%$ FYM (25t ha-1) $\left(\mathrm{T}_{2}\right)$; Soil Test Crop Response targeted yield (155:150:129 kg NPK ha- $\left.{ }^{-1}\right)\left(\mathrm{T}_{3}\right) ; 50 \% \mathrm{RDF}+$ 100\% FYM + Azotobacter $\left(12 \mathrm{~kg} \mathrm{ha}^{-1}\right)+$ Phosphobacteria $\left(\mathrm{kg} \mathrm{ha}^{-1}\right)\left(\mathrm{T}_{4}\right) ; 75 \% \mathrm{RDF}+\mathrm{VC}\left(1.5 \mathrm{t} \mathrm{ha}^{-1}\right)+$ Azotobacter $\left(12 \mathrm{~kg} \mathrm{ha}^{-1}\right)+$ Phosphobacteria $\left(12 \mathrm{~kg} \mathrm{ha}^{-1}\right)\left(\mathrm{T}_{5}\right) ; 50 \% \mathrm{RDF}+$ Azotobacter $\left(12 \mathrm{~kg} \mathrm{ha}^{-1}\right)+$ Phosphobacteria $\left(12 \mathrm{~kg} \mathrm{ha}^{-1}\right)\left(\mathrm{T}_{6}\right) ; 50 \% \mathrm{RDF}+50 \% \mathrm{FYM}+\mathrm{VC}\left(1.5 \mathrm{t} \mathrm{ha}^{-1}\right)+$ Azotobacter $\left(12 \mathrm{~kg} \mathrm{ha}^{-1}\right)+$ Phosphobacteria $\left(12 \mathrm{~kg} \mathrm{ha}^{-1}\right)\left(\mathrm{T}_{7}\right) ; 100 \% \mathrm{FYM}+50 \%$ Nitrogen supplied through neem cake $\left(62.5 \mathrm{~kg} \mathrm{ha}^{-}\right.$ $\left.{ }^{1}\right)+$ Azotobacter $\left(12 \mathrm{~kg} \mathrm{ha}^{-1}\right)\left(\mathrm{T}_{8}\right) ; 100 \% \mathrm{FYM}+50 \%$ nitrogen supplied through poultry manure (1.5t ha-

$\left.{ }^{1}\right)+$ Azotobacter $\left(12 \mathrm{~kg} \mathrm{ha}^{-1}\right)\left(\mathrm{T}_{9}\right)$ and 100\% FYM + 50 \% FYM supplied through vermicompost (1.5 $\mathrm{t} \mathrm{ha}^{-}$

$\left.{ }^{1}\right)+$ Azotobacter $\left(12 \mathrm{~kg} \mathrm{ha}^{-1}\right)\left(\mathrm{T}_{10}\right)$ (Paul et al., 2002, Banafar et al., 2005, Singh et al., 2007) ${ }^{13,2,18}$. The 
variety used was Kufri Jyoti; it is a most popular variety in Eastern dry zone of Karnataka (Marwaha et al., $2010)^{10}$. The recommended dose of NPK (125:100:125 kg ha-1) Farmyard manure (25 t ha-1),

Vermicompost $\left(1.5 \mathrm{t} \mathrm{ha}^{-1}\right)$ and bio-fertilizers like Azotobacter $\left(12 \mathrm{~kg} \mathrm{ha}^{-1}\right)$ and Phosphobacteria (12 kg $\mathrm{ha}^{-1}$ ) were applied as per the treatments. Fifty percent of $\mathrm{N}$ and full dose of $\mathrm{P}$ and $\mathrm{K}$ were applied in the furrows as per treatments and were thoroughly mixed in soil. The remaining half of the nitrogen was top dressed at 30 days after planting. The observations on yield and quality attributes were recorded at 90 days after planting.

\section{Result And Discussion}

Integrated nutrient management significantly influenced yield and quality of potato crop. The plants supplied with $50 \% \mathrm{RDF}+50 \% \mathrm{FYM}+\mathrm{AZT}+\mathrm{PSB}\left(\mathrm{T}_{2}\right)$ recorded highest number of tubers per plant (7.87), tuber yield per plant (363.33 $\left.\mathrm{g} \mathrm{plant}^{-1}\right)$, tuber plot yield $\left(21.50 \mathrm{~kg} \mathrm{plot}^{-1}\right)$ and tuber yield per hectare (34.13 $\mathrm{t} \mathrm{ha}^{-1}$ ) which was on par with the treatments of $T_{3}, T_{4}$ and $T_{6}$, respectively (Table.1). The increase in number of tubers per plant could be attributed to increased vegetative growth observed due to balanced nutrient levels, which stimulated initiation of more stolon, thus increasing the number of tubers per plant. The increased tuber yield was attributed to better photosynthesis activity and accumulation of carbohydrates which helps in better growth of tubers. Potato tuber yield is also known to be influenced by $P$ fertilizers through its effect on the number of tubers produced, the size of the tubers and the time at which maximum yield is obtained $\left(T_{3}\right)$. The increased tuber yields due to integrated nutrient management of the above said fertilizer levels have resulted in more vegetative growth and accumulation of more photosynthates. Thus, there may be more translocation of photosynthates to sink. Hence, they have resulted in more tuber yield. Higher number of tubers per hill also contributed to significantly higher total tuber yield. The favourable effect of integrated nutrient management through both inorganic fertilizers and organic manures on increasing the tuber yield. Production was also noticed by Kumar et al. (2011) ${ }^{8}$ and Das et al. (2009) ${ }^{4}$. Use of bio-fertilizer exerted significant effect on influencing yield of tubers during the study. Interaction effect of nutrient management and biofertilizers was found significant in influencing the yield per plot and per hectare of the crop. The results agreed with findings of Singh et al. $(2007)^{18}$, Manoj Kumar et al. (2012) ${ }^{9}$ and Sasani et al. (2003) ${ }^{15}$ in potato. Jaipaul et al. $(2011)^{7}$ reported that higher tuber yield under integrated use of inorganics + organics and chicken manure + bio-fertilizer probably reflect the greater nutrients availability under these treatments (Table 1).

Table 1: Effect of integrated nutrient management on number of tubers, tuber yield per plant, plot yield and total yield of potato at harvest 


\begin{tabular}{|c|c|c|c|c|}
\hline \multirow[t]{2}{*}{ Treatments } & \multirow[t]{2}{*}{ No. of tuber plant ${ }^{-1}$} & \multicolumn{3}{|l|}{ Tuber yield } \\
\hline & & Yield plant $^{-1}(\mathrm{~g})$ & Plot yield (kg) & Total yield $\left(t \mathrm{ha}^{-1}\right)$ \\
\hline $\mathrm{T}_{1}$ & 5.00 & 243.33 & 14.51 & 23.03 \\
\hline $\mathrm{T}_{2}$ & 5.33 & 250.00 & 15.87 & 25.19 \\
\hline $\mathrm{T}_{3}$ & 6.87 & 330.00 & 20.63 & 32.74 \\
\hline $\mathrm{T}_{4}$ & 6.73 & 299.33 & 17.33 & 27.55 \\
\hline $\mathrm{T}_{5}$ & 6.67 & 283.00 & 16.83 & 26.71 \\
\hline $\mathrm{T}_{6}$ & 6.13 & 272.33 & 16.08 & 25.52 \\
\hline $\mathrm{T}_{7}$ & 7.87 & 363.33 & 21.50 & 34.13 \\
\hline $\mathrm{T}_{8}$ & 4.73 & 184.67 & 12.40 & 20.00 \\
\hline $\mathrm{T}_{9}$ & 5.33 & 260.33 & 15.36 & 24.38 \\
\hline $\mathrm{T}_{10}$ & 5.27 & 244.67 & 14.59 & 23.16 \\
\hline SE $m \pm$ & 0.71 & 45.39 & 2.38 & 2.26 \\
\hline CD at $5 \%$ & 1.49 & 95.37 & 5.01 & 4.75 \\
\hline CV (\%) & 14.64 & 20.33 & 16.64 & 9.07 \\
\hline
\end{tabular}

Significantly higher tuber dry matter $(21.67 \%)$, starch content $(78.20 \%)$ non-reducing sugars $(0.84 \%)$ and total sugars (1.74\%) was recorded in plants provided with 50\% RDF + 50\% FYM + Azotobacter + Phosphobacteria $\left(T_{7}\right)$ which was on par with $T_{3}$ (Table.2). The increased dry matter accumulation could be attributed to better vegetative growth and production of more fresh weight. Increased dry matter accumulation was also related to better uptake of nutrients due to the influence of biofertilizers supplied along with chemical fertilizers and organic manures. The better absorption and accumulation of nutrients promoted growth and metabolism. This in turn resulted in production of more dry matter accumulation. Similar results were also reported by Baniuniene and Zekaite (2008) ${ }^{3}$, Shamorady (2010) ${ }^{17}$ and Gayathri et al. (2009) ${ }^{6}$ in fertilizer doses applied along with FYM and Azospirillum in potato.

Increased starch content was related to better uptake of nutrients due to the influence of biofertilizers supplied along with chemical fertilizers and organic manures. This effect was also due to bacterial activity that enhanced the crop growth during the advanced phase. The increase in starch content was due to increased supply of nutrients in general and potassium. Potassium played an important role in the activation of starch synthetase and helped in translocation of starch from leaves to tubers. The results 
obtained agreed with those reported by Nandekar et al. (2006) ${ }^{12}$, Jaipaul et al. (2011) ${ }^{7}$, Shambhavi and Sharma (2008b) ${ }^{16}$ and Mondal et al. (2007) ${ }^{11}$ (Table 1).

Table 2

Effect of integrated nutrient management on quality parameters of potato

\begin{tabular}{|llllll|}
\hline Treatments & $\begin{array}{l}\text { Tuber dry } \\
\text { matter (\%) }\end{array}$ & $\begin{array}{l}\text { Starch } \\
(\%)\end{array}$ & $\begin{array}{l}\text { Reducing } \\
\text { sugars }(\%)\end{array}$ & $\begin{array}{l}\text { Non-reducing } \\
\text { sugars (\%) }\end{array}$ & $\begin{array}{l}\text { Total sugars } \\
(\%)\end{array}$ \\
\hline $\mathrm{T}_{1}$ & 16.64 & 70.46 & 0.85 & 0.58 & 1.43 \\
\hline $\mathrm{T}_{2}$ & 17.81 & 72.32 & 0.83 & 0.59 & 1.42 \\
\hline $\mathrm{T}_{3}$ & 20.53 & 73.31 & 0.87 & 0.75 & 1.62 \\
\hline $\mathrm{T}_{4}$ & 19.79 & 73.88 & 0.87 & 0.78 & 1.65 \\
\hline $\mathrm{T}_{5}$ & 19.19 & 73.21 & 0.87 & 0.74 & 1.61 \\
\hline $\mathrm{T}_{6}$ & 18.42 & 72.91 & 0.86 & 0.64 & 1.50 \\
\hline $\mathrm{T}_{7}$ & 21.67 & 78.20 & 0.90 & 0.84 & 1.74 \\
\hline $\mathrm{T}_{8}$ & 15.32 & 68.96 & 0.82 & 0.58 & 1.40 \\
\hline $\mathrm{T}_{9}$ & 18.55 & 71.99 & 0.85 & 0.60 & 1.45 \\
\hline $\mathrm{T}_{10}$ & 16.87 & 70.53 & 0.83 & 0.58 & 1.41 \\
\hline $\mathrm{SE} m \pm$ & 0.75 & 1.50 & 0.03 & 0.06 & 0.07 \\
\hline $\mathrm{CD}$ at $5 \%$ & 1.58 & 3.16 & $\mathrm{NS}$ & 0.12 & 0.15 \\
\hline $\mathrm{CV}(\%)$ & 7.50 & 2.53 & 4.39 & 10.82 & 5.57 \\
\hline
\end{tabular}

The higher accumulation of sugars in the tubers (1.74\%) was due to better availability of nutrients and synthesis of sugars when plants received combined chemical fertilizers, organic manures and biofertilizers. It was also related to application of biofertilizers especially Azotobacter that helped in fixation of atmospheric nitrogen while the applied FYM improved the soil physical and chemical properties which aided in accumulation of more sugars $\left(T_{10}\right)$. The higher sugar content under integrated use of inorganics + organics and vermicompost + bio-fertilizer reflected the greater nutrients availability under this treatment. The supply of nutrients to potato crop through inorganic sources of nutrients provided higher amount of plant available nutrients during different growth and development stages and if the potassium availability remained optimum or high, then it resulted, in reduction of reducing sugar in potato. The results are in conformity with the findings of Jaipaul et al. (2011) ${ }^{7}$, Mondal et al. (2007) ${ }^{11}$, Sud et al. $(2007)^{21}$, Sarkar et al. (2007) ${ }^{14}$ and in potato crop. 


\section{Conclusion}

During the study, plants provided with 50\% RDF + 50\% FYM + VC + AZT + PSB recorded maximum number of tubers per plant, tuber yield per plant, tuber yield per plot and per hectare, higher tuber girth and higher tuber length. The maximum marketable tuber yield per plot and per hectare and the maximum grade $D$, grade $B$ and grade A tuber yield in potato plants were recorded with application of $50 \%$ RDF $+50 \% \mathrm{FYM}+$ $V C+A Z T+P S B$.

In terms of quality characters, maximum tuber dry matter, starch content, reducing sugars, non-reducing sugars and total sugars; as a regard the nutrients accumulation in different plant parts of potato recorded maximum nitrogen, phosphorus and potassium in stem, leaf and tuber respectively were observed in plants received $50 \% \mathrm{RDF}+50 \% \mathrm{FYM}+\mathrm{VC}+\mathrm{AZT}+\mathrm{PSB}$.

Therefore, this fertilizer combination can be recommended for application in cultivation of potato in the Eastern dry zone of Karnataka.

\section{References}

1. ANONYMOUS, 2010, The Hindu, Survey of Indian Agriculture, pp:64-66

2. BANAFAR, R. N. S., BILLORE, M. A. N. D. \& KUSHWAH, S. S. Integrated plant nutrition approaches for potato. Potato J. 32, 3-4 (2005).

3. AND ZEKAITE, B. A. N. I. U. N. I. E. N. E. A. V 2008, the effect of mineral and organic fertilizers on potato tuber yield and quality, AGRONOMIJAS VĒSTIS (Latvian Journal of Agronomy), No.11, LLU

4. DAS, P. P. \& A. AND ZAMEN, S. A. R. K. A. R. A 2009, Response of organic and inorganic sources of nutrients on growth and yield of potato in Gangetic alluvial plains of west Bengal, Proc. 96th Indian Science Congress, part-II (Abstract), held on 3-7th January at NEHU, Shillong, Meghalaya.

5. DIBYENDU, CHATTERJEE \& AJAYA SRIVASTAVA AND R. K SINGH Fertilizer recommendations based on targeted yield concept involving integrated nutrient management for potato (Solanum tuberosum) in tarai belt of Uttarakhand. Indian Journal of Agricultural Sciences. 80 (12), 1048-1053 (2010).

6. GAYATHRI, A., VADIVEL, A., SANTHI, R., MURUGESA BOOPATHI, P. \& NATESAN, R. AND 2009, Soil testbased fertilizer recommendation under integrated plant nutrition system for potato (Solanum tuberosum L.) in hilly tracts of Nilgiris district, Indian J. Agric. Res., 43(1): 52-56.

7. JAIPAUL, SANJEEV SHARMA AND ASHOK, K. S. H. A. R. M. A. Effect of organic fertilizers on growth, yield and quality of potato under rainfed conditions of Central Himalayan Region of Uttarakhand. Potato J. 38 (2), 176-181 (2011).

8. KUMAR MANOJ, B. A. I. S. H. Y. A. L. K., GUPTA, G. H. O. S. H. D. C. \& V.K Yield and quality of potato (Solanum tuberosum) tubers as influenced by nutrient sources under rainfed condition of Meghalaya. Indian Journal of Agronomy. 56 (3), 260-266 (2011).

9. KUMAR MANOJ, B. A. I. S. H. Y. A. L. K., DUBEY, G. H. O. S. H. D. C. G. U. P. T. A. V. K., ANUP DAS AND PATEL, S. K. \& D.P Productivity and soil health of potato (Solanum tuberosum L.) Field as influenced 
by organic manures, inorganic fertilizers, and bio-fertilizers under high altitudes of Eastern Himalayas. J. Agri. Sci. 4, No. 5 (2012).

10. Marwaha, R. S., Pandey, S. K., Kumar, D., Singh, S. V. \& Kumar, P. Potato processing scenario in India: Industrial constraints, future projections, challenges ahead and remedies. J Food Sci Technol. 47 (2), 137-156 (2010).

11. MONDAL, S. S., SAHA MITHUN, A. C. H. A. R. Y. A. D. \& CHATTERJEE, P. A. T. R. A. D. S 2007, Integrated effect of nitrogen and potassium with or without sulphur and farm yard manure on potato tuber yield, storage quality and soil fertility status, Potato J., 34(1 and 2): 97-98.

12. NANDEKAR, D. N., SAWARKAR, S. D. \& AND NAIDU, A. K. Effect of biofertilizers and NPK on the growth and yield of potato in Satpura plateau. Potato Journal. 33, 168-169 (2006).

13. PAUL KHURANA, S. M., SHEKHAWAT, G. S. \& SINGH, P. A. N. D. E. Y. S. K. B.P 2002, Potassium and integrated nutrient management in potato, Indian Potato Association, Shimla; Potato, Global Research and Development, 2: 744-754

14. SARKAR, B., NAYEK, M. A. N. D. A. L. S. S., SAHA, S. S., AND BISWAS, M. \& S Integrated nutrient management for the productivity and quality improvement of potato under irrigated condition. Potato J. 34 (1-2), 99-100 (2007).

15. SASANI, G. V., PATEL, C. K., PATEL, R. N. \& AND PATEL, N. H. Effect of inorganic fertilizers with and without organic manures on yield of potato in north Gujarat. J. Indian Potato Assoc. 30 (1-2), 77-78 (2003).

16. SHAMBHAVI, S. \& AND SHARMA R, P. Influence of vermicompost on quality of potato (Solanum tuberosum) in wet temperate zone of Himachal Pradesh. Indian J Plant Physiol. 13, 185-190 (2008b).

17. SHAMORADY R., 2010, Effect of Utilization of Organic and Inorganic Nitrogen Source on the Potato Shoots Dry Matter, Leaf Area Index and Plant Height, During Middle Stage of Growth,International Journal of Agricultural and Biological Sciences1:1

18. SINGH, S. N., SINGH, B. P., SINGH, O. P., SINGH, R. \& AND SINGH, R. K. Effect of nitrogen application in conjunction with bio-inoculant on the growth, yield and quality of potato under Indo-Gangetic plain region. Potato Journal. 34, 103-104 (2007).

19. SINGH, S. N., SINGH, B. P., SINGH, O. P., SINGH, R. \& AND SINGH, R. K. Effect of nitrogen application in conjunction with bio-inoculant on the growth, yield and quality of potato under indo-gangetic plain region. Potato J. 34, 103-104 (2007).

20. SINGH, S. P. \& AND KUSHWAH, V. S. Effect of integrated use of organic and inorganic sources of nutrients on potato (Solanum tuberosum L.) production. Indian journal of Agronomy. 51 (3), 236238 (2006).

21. SUD, K. C. \& AND JATAV, M. K. Response of potato to phosphorus solubilizing bacteria in Brown Hill of Shimla. Potato J. 34 (1-2), 109-110 (2007). 